\title{
Effect of sediment copper on benthic fauna
}

\author{
Brage Rygg \\ Norwegian Institute for Water Research, P.O. Box 333, Blindern, N-0314 Oslo 3, Norway
}

\begin{abstract}
Relations between species diversity in benthic-fauna communities and sediment concentration of heavy metals $(\mathrm{Cu}, \mathrm{Pb}, \mathrm{Zn})$ and organic matter were tested by correlation and regression analyses on data from Norwegian fjords. Diversity and $\mathrm{Cu}$ showed a strong negative correlation. A moderate negative correlation was found for $\mathrm{Pb}$ and a weak negative correlation for $\mathrm{Zn}$. Diversity and organic matter showed a moderate negative correlation. The negative correlation between diversity and $\mathrm{Cu}$ is interpreted as a cause-effect correlation, with high copper concentrations being toxic to a number of species, thus lowering diversity. Correlation plots were made between $\mathrm{Cu}$ and occurrence of selected species. Among the 50 most frequently occurring species, 20 were significantly missing from more copper-polluted ( $\mathrm{Cu}>200 \mathrm{ppm})$ stations.
\end{abstract}

\section{INTRODUCTION}

Pollution-induced changes in marine benthic communities have been subject to a number of investigations during the last decades. Most extensively studied are the effects of organic pollution and eutrophication (Pearson \& Rosenberg 1978). A variety of techniques are in use to assess the pollution effects on communities and to separate these effects from natural environmental variability (Gray \& Pearson 1982). It is well documented that pollution often leads to structural changes in benthic communities, as revealed by diversity measurements (Pearson \& Rosenberg 1978). A few tolerant or opportunistic species will become relatively more numerous and will dominate the community, while many less tolerant species will become increasingly rare or disappear. Species which are sensitive to pollution may be used as indicator species (Leppäkoski 1975, Pearson \& Rosenberg 1978, Pearson et al. 1983). Deviation from the log-normal distribution of the number of individuals among species was interpreted by Gray \& Mirza (1979) as an effect of environmental disturbance, and was proposed a basis for identifying groups of species potentially indicative of conditions involving organic pollution (Gray \& Pearson 1982, Pearson et al. 1983). It was not known if the same would be true for other forms of pollution (Gray 1979). Bryan (1976) stated that an increase in the concentrations of some of the more toxic metals in sea water by a factor of 10 might be expected to have fairly obvious ecological effects. However, Bryan was concerned about the difficulty in detecting subtle ecological effects and gradual changes, and believed that effects resulting from metal contamination have gone unnoticed unless extremely obvious.

Studies in a number of fjords in Norway showed negative correlation between the diversity of benthic fauna and pollutant discharge amounts and proximity to discharge areas (Rygg \& Skei 1984).

The aims of the present study were to investigate the correlation between concentrations of some heavy metals in the sediment and (1) the diversity of species in the community, (2) the occurrence of single species.

\section{MATERIAL AND METHODS}

The study was based on fauna lists and sediment chemical analyses from 71 stations in a dozen fjord areas with varying degrees of pollution. The material was obtained during several projects in 1977-1983, mostly within the national pollution monitoring programme. Descriptions of the areas and the sources, types and amounts of pollution are given by Rygg (1984) and (in part) by Rygg \& Skei (1984).

Samples of fauna were taken by grabs and sieved through steel plates perforated by $1.0 \mathrm{~mm}$ round holes (Hovgaard 1973). The retained material was sorted and identified in the laboratory. Sediment cores were taken by a gravity corer (Niemistö 1974). Surface sediment bulk samples were decomposed using conc. $\mathrm{HNO}_{3}$ and analysed for concentration of metals, excluding the 
silicious fraction, based on dry sediment weight. Sediment organic content was determined by weight loss on ignition, or by conversion of carbon data to organic content values by the factor 1.724 (Jackson 1962).

The diversity measure used in this study was given by Hurlbert (1971):

$$
E\left(S_{n}\right)=\sum_{i}\left[1-\frac{\left(\begin{array}{c}
N-N_{i} \\
n
\end{array}\right)}{\left(\begin{array}{c}
N \\
n
\end{array}\right)}\right]
$$

where $\mathrm{N}=$ the total number of individuals in the whole sample; $\mathrm{N}_{\mathrm{i}}=$ number of individuals of species $\mathrm{i}_{\text {; }}$ $\mathrm{n}=$ the total number of individuals in a sample $\mathrm{n} / \mathrm{N}$ the size of the whole sample; $E\left(S_{n}\right)=$ the expected number of species in a sample $n / N$ the size of the whole sample. The value $n=100$ was chosen for the $E\left(S_{n}\right)$ used in the correlation analyses.

\section{RESULTS}

To test if the diversity of the benthic fauna was correlated with the concentrations of metals in the sediment, diversity $\left[E\left(S_{n}\right)\right]$ was plotted against the concentration of copper (Cu), zinc ( $\mathrm{Zn})$ and lead $(\mathrm{Pb})$ on a $\log / \log$ scale (Fig. 1 to 3). Regression and correlation analyses were made to quantify the relation. The regression line through the plot is shown. Below the plot, the equation for the regression line (Y), the correlation coefficient $(\mathrm{R})$, the probability of the correlation

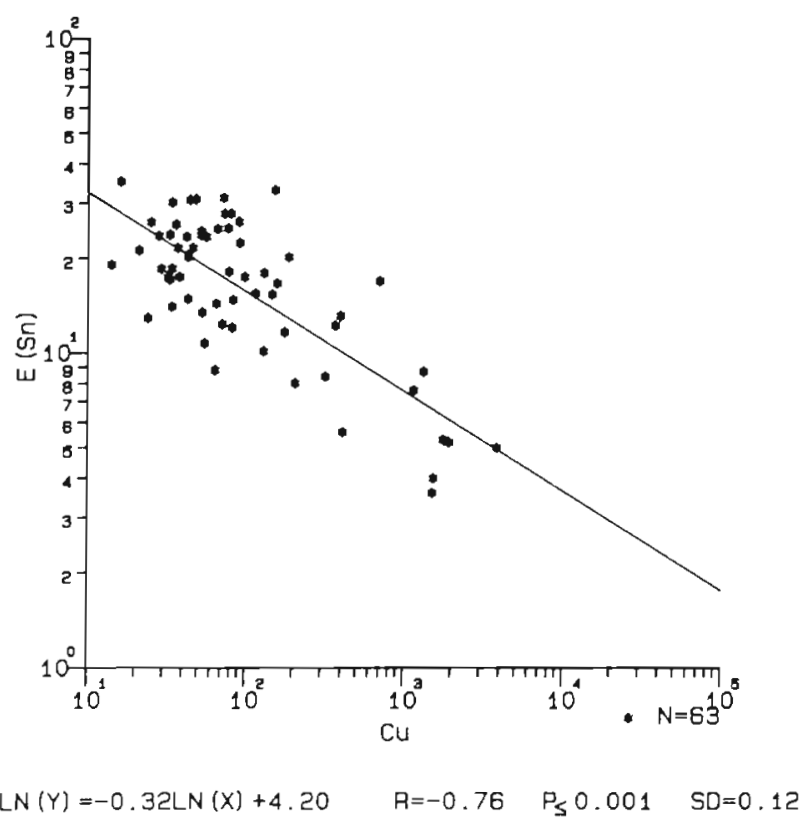

Fig. 1 Correlation and regression analyses of the relation between fauna diversity, $E\left(S_{n}\right)$, and sediment copper concentration $(\mathrm{Cu})$ (ppm dry weight). $\mathrm{LN}=\log$ to base 10

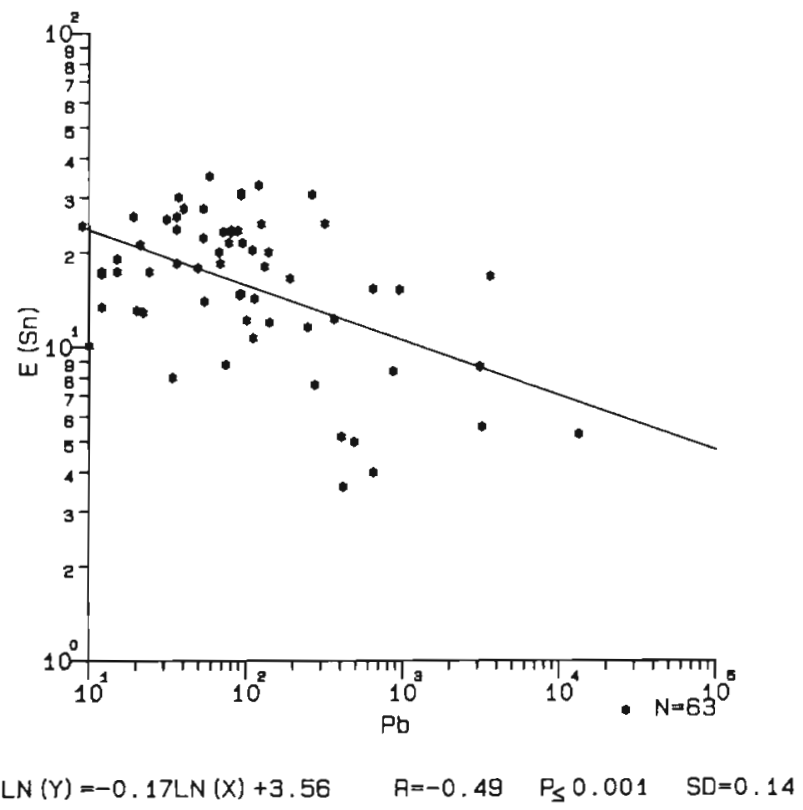

Fig. 2. Correlation and regression analyses of the relation between fauna diversity and sediment lead concentration

(Pb) (ppm dry weight)

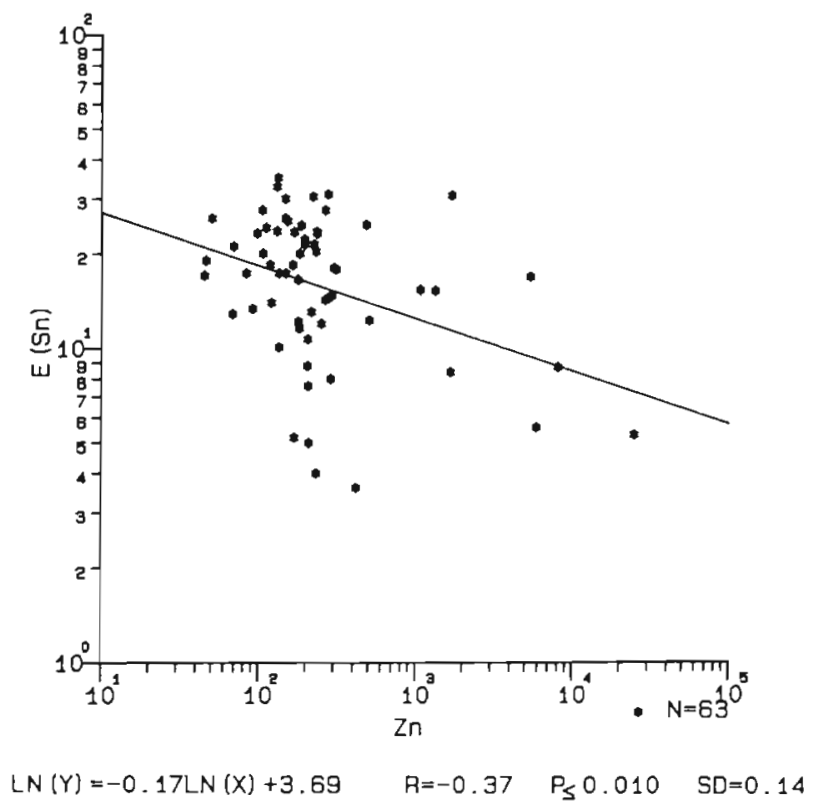

Fig. 3. Correlation and regression analyses of the relation between fauna diversity and sediment zinc concentration ( $\mathrm{Zn}$ ) (ppm dry weight)

being purely accidental (P), and the maximum deviation (SD) of the regression coefficient at confidence level 1-P, are given.

The correlation coefficients $(R)$ on a $\log$-log scale between diversity and each metal, and between the concentrations of each metal, are shown in Table 1. 
Table 1. Correlation coefficients

\begin{tabular}{|cccc|}
\hline & $\mathrm{E}(\mathrm{S})$ & $\mathrm{Cu}$ & $\mathrm{Zn}$ \\
\hline $\mathrm{Cu}$ & -0.76 & & \\
$\mathrm{Zn}$ & -0.37 & 0.54 & \\
$\mathrm{~Pb}$ & -0.49 & 0.65 & 0.85 \\
\hline
\end{tabular}

$\mathrm{E}\left(\mathrm{S}_{\mathrm{n}}\right)$ and $\mathrm{Cu}$ showed a strong negative correlation $(-0.76)$. A moderate negative correlation $(-0.49)$ was found for $\mathrm{E}\left(\mathrm{S}_{\mathrm{n}}\right)$ with $\mathrm{Pb}$. A weak negative correlation $(-0.37)$ was found for $E\left(S_{n}\right)$ with $Z n$. The most probable regression coefficient for $\mathrm{E}\left(\mathrm{S}_{\mathrm{n}}\right)$ on $\mathrm{Cu}$ on a $\log / \mathrm{log}$ scale was found to be -0.32 (Fig. 1), which means that the number of species is roughly halved for each $10-$ fold increase in the copper concentration.

In order to test if sediment organic content affected sediment copper levels, data from 84 samples from several fjords were analysed. Data from 13 samples in polluted areas having copper concentrations above $500 \mathrm{ppm}$ were excluded from the regression analyses, because pollutant input there was assumed to dominate over sorption processes in determining sediment copper levels. No correlation was found between organic content and copper in the 71 samples (Fig. 4).

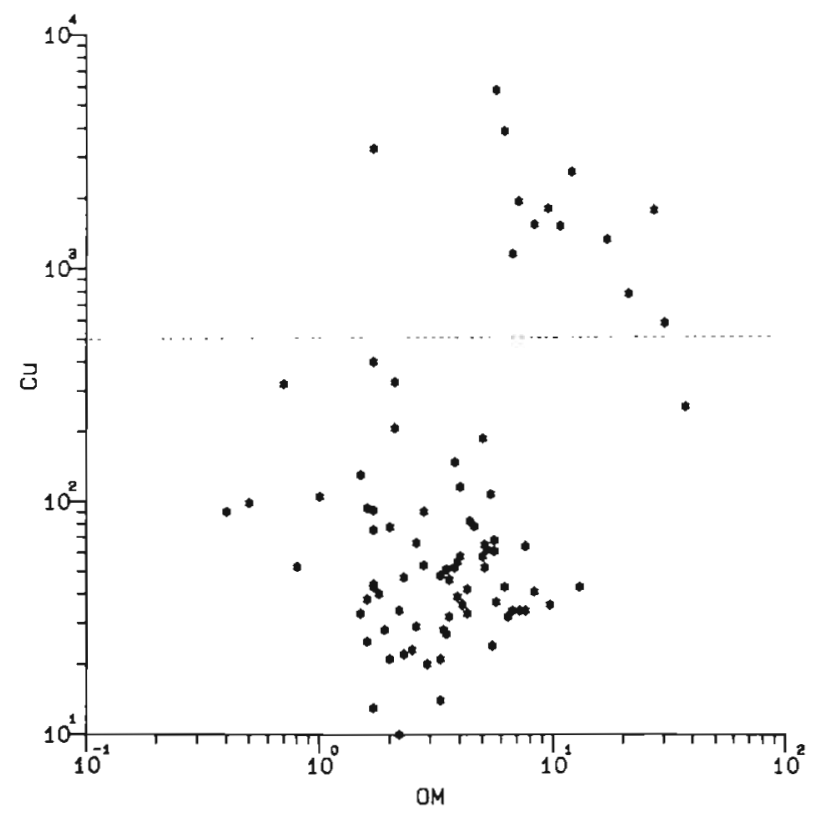

$L N(Y)=-0.09 L N(X)+4.05 \quad R=-0.09 \quad P_{\leq} 1.000 \quad S D=-0.09$

Fig. 4. Correlation analyses of the relation between copper concentration $(\mathrm{Cu})$ and organic content $(\mathrm{OM})$ (\% dry weight) in 84 sediment samples from Norwegian fjords. Data from the 13 stations with $\mathrm{Cu}>500 \mathrm{ppm}$ (above dotted line) were excluded from the statistical analyses shown below the plot
Analyses of the correlation between sediment copper and diversity, and between sediment organic content and diversity, were also made on data from only the 4 most polluted fjords (Nordrana, Orkdalsfjorden, Sørfjorden, and Kristiansandsfjorden; Rygg \& Skei 1984). At the 28 stations, there was a better correlation between low diversity and $\mathrm{Cu}$ than between low diversity and organic content (Fig. 5 \& 6).

The benthic-fauna community in a fjord normally consists of several hundred species. A reduction in the diversity thus indicates that a considerable number of species have become rare or absent. In order to identify

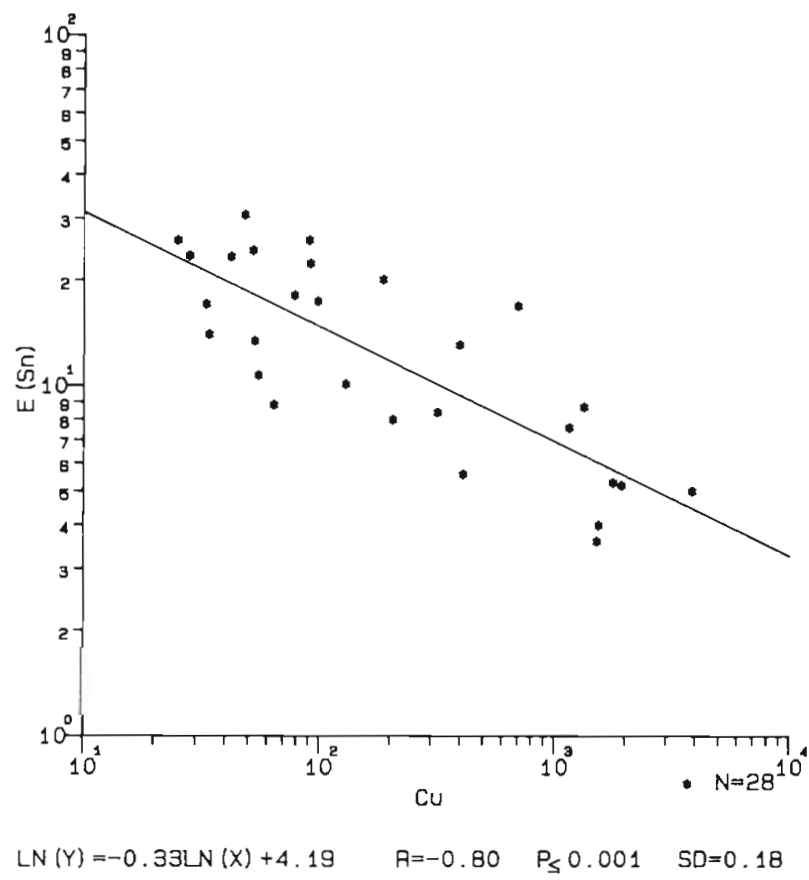

Fig. 5. Correlation and regression analyses of the relation between fauna diversity and sediment copper concentration in 4 polluted fjords. Data used in Fig. $5 \& 6$ are from the same samples

species susceptible to copper pollution, correlation plots were made between sediment copper concentration and the occurrence of selected species. Species that did not occur at copper concentrations above $200 \mathrm{mg} \mathrm{kg}^{-1}$ (= ppm) were defined as non-tolerant species. This concentration was chosen because it is approximately 10 times higher than background values, and correlates with a $50 \%$ reduction in diversity (Fig. 1). Only species with 13 or more occurrences among the 71 stations were included in the analysis, thus making the absence of any of them from the 12 stations with copper concentrations above $200 \mathrm{ppm}$ significant at the $95 \%$ level. In addition, 5 less frequently occurring polychaete species, Anaitides groenlandica, Capitella capitata, Cirratulus cirratus, 


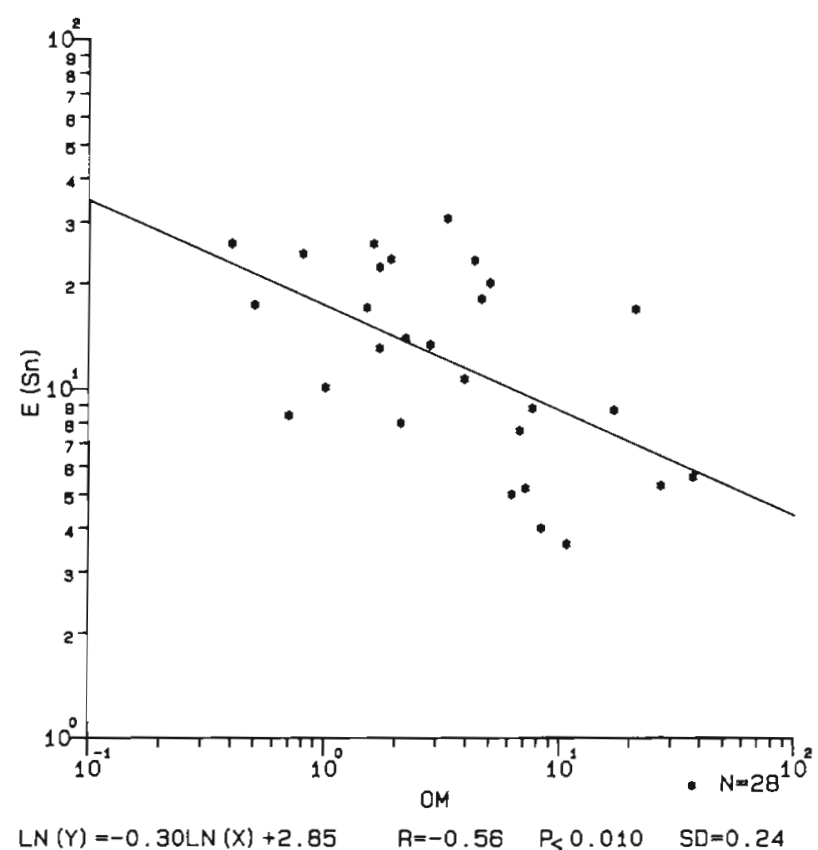

Fig. 6. Correlation and regression analyses of the relation between fauna diversity and sediment organic content in 4 polluted fjords. Data used in Fig. 5 \& 6 are from the same samples

Eteone longa and Nereimyra punctata, found at some of the highly copper-polluted stations, were included.

Among the 50 most frequently occurring species, 20 were significantly missing from the more copper-polluted $(\mathrm{Cu}>200 \mathrm{ppm})$ stations; they were classified as non-tolerant species (Table 2). The other species were

Table 2. Non-tolerant species, absent from stations with sediment copper concentrations above $200 \mathrm{ppm}$. C: carnivore

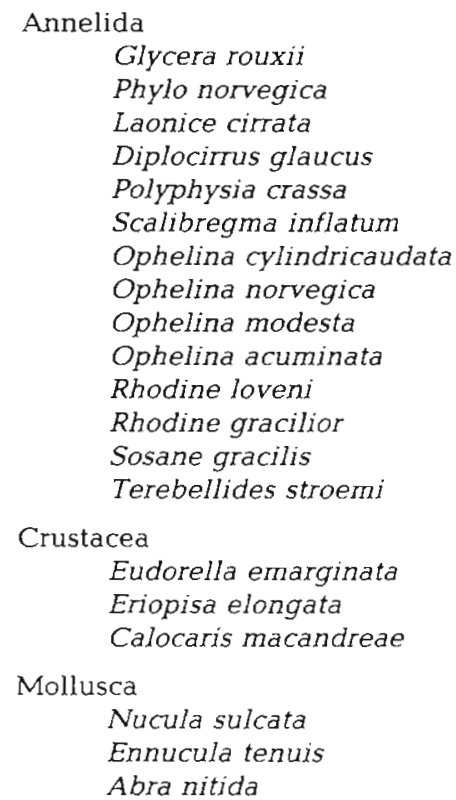

present at one or more of these stations. Some were only occasionally found at one of the more copperpolluted stations, but were common at less polluted stations. They too were classified as non-tolerant species (Table 3). Some of the species which occurred

Table 3. Non-tolerant species, anly occasionally found at stations with sediment copper concentrations above $200 \mathrm{ppm}$, but common at less polluted stations. C: carnivore

\begin{tabular}{|c|c|}
\hline $\begin{array}{l}\text { Annelida } \\
\text { Paraphinome jeffreysii } \\
\text { Lumbrineris spp. } \\
\text { Paraonis gracilis } \\
\text { Prionospio cirrifera } \\
\text { Spiophanes kroeyeri } \\
\text { Melinna cristata }\end{array}$ & (C) \\
\hline $\begin{array}{l}\text { Mollusca } \\
\quad \text { Thyasira equalis }\end{array}$ & \\
\hline $\begin{array}{l}\text { Echinodermata } \\
\text { Amphiura chiajei } \\
\text { Amphiura filiformis }\end{array}$ & \\
\hline
\end{tabular}

at the more copper-polluted stations were classified as moderately tolerant (Table 4). Species which were common at the most copper-polluted stations were classified as highly tolerant (Table 5). Plots of the occurrence of 4 species which were significantly missing at the stations with a high sediment copper concentration are shown in Fig. 7, and in Fig. 8, of 4 species which were common at copper-polluted stations.

Relation between feeding type of animal and tolerance was considered. Carnivores were compared with the other feeding types, mainly deposit feeders. Motile, carnivorous polychaetes (Fauchald \& Jumars 1979) are indicated by a $C$ in Table 2 to 5 . Of the total of 52 species (or genera), 11 were classified as carnivores. Nine of them, or $82 \%$, were tolerant species (Table $4 \& 5$ ). Of the 41 species not classified as carnivores, 14 , or only $34 \%$, were tolerant species.

Table 4. Moderately tolerant species, present at some of the stations with sediment copper concentrations above $200 \mathrm{ppm}$.

$$
\text { C: carnivore }
$$

Annelida

Ceratocephale loveni

Nephtys paradoxa

Nephtys ciliata

Prionospio malmgreni

Tharyx marioni

Mollusca

Thyasira flexuosa

Thyasira sarsi

Corbula gibba 
Table 5. Highly tolerant species, common at the most copperpolluted stations. C: carnivore

\begin{tabular}{|cc|}
\hline Annelida & \\
Pholoe minuta & (C) \\
Eteone longa & (C) \\
Anaitides groenlandica & (C) \\
Nereimyra punctata & (C) \\
Ophiodromus flexuosus & (C) \\
Glycera alba & (C) \\
Goniada maculata & (C) \\
Polydora spp. & \\
Scoloplos armiger & \\
Cirratulus cirratus & \\
Chaetozone setosa & \\
Cossura longocirrata & \\
Capitella capitata & \\
Heteromastus filiformis & \\
Tubificoides spp. & \\
\hline
\end{tabular}

\section{DISCUSSION}

The significant negative correlation between fauna diversity and copper concentration may be explained as a cause-effect correlation, with high copper concentrations being toxic to a number of species, thus

Eriopisa elongata
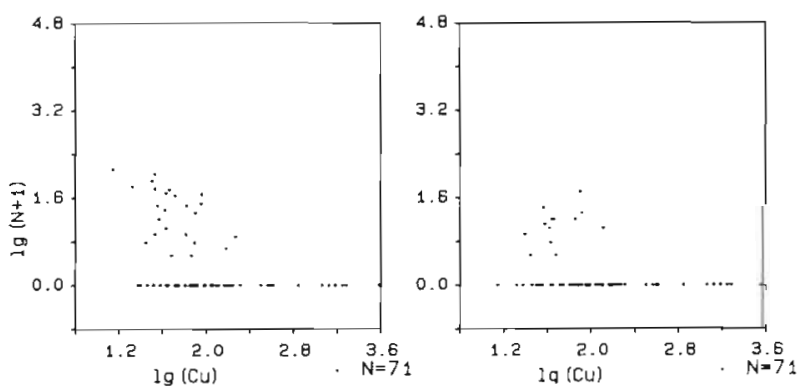

Polyphysia crassa

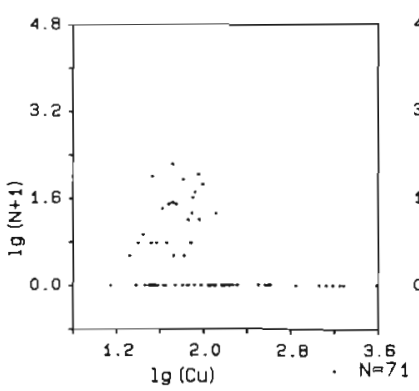

Fig. 7. Plots of the occurrence of 4 selected species (the amphipod Eriopisa elongata and the polychaetes Glycera rouxii, Polyphysia crassa and Terebellides stroemi) significantly missing at stations with $\mathrm{Cu}$ higher than $200 \mathrm{ppm}$, i.e. classified as non-tolerant species (Table 2). Cu: copper concentration (ppm dry weight); $\mathrm{N}$ : number of individuals $\mathrm{m}^{-2}$. The $\lg (\mathrm{Cu})$ value 2.3 corresponds to $200 \mathrm{ppm}$
Glycera alba
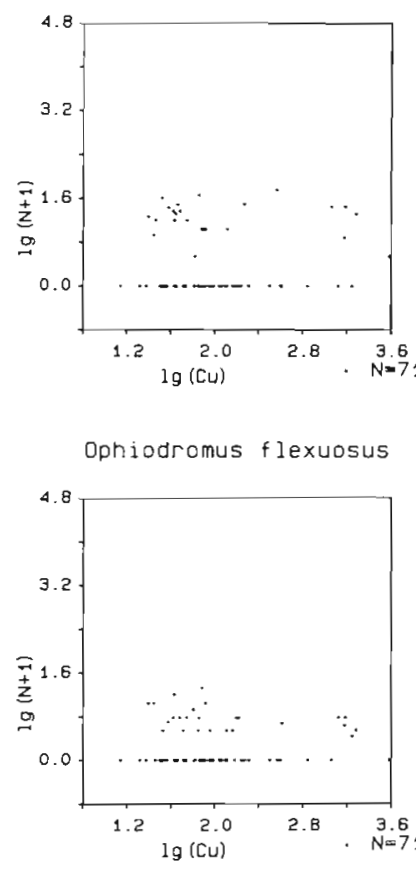

Ophiodromus flexuosus
Chaetozone setosa

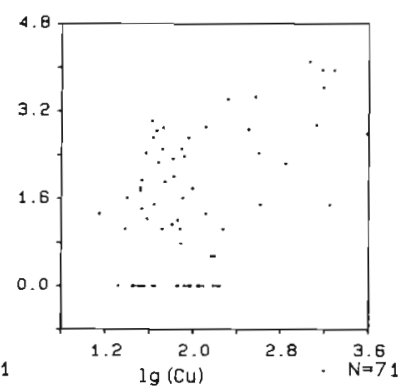

Pholoe minuta

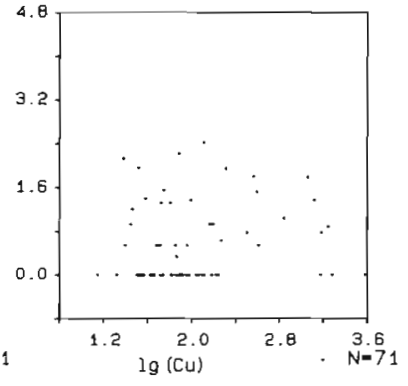

Fig. 8. Plots of the occurrence of 4 selected species (the polychaetes Glycera alba, Chaetozone setosa, Ophiodromus flexuosus and Pholoe minuta) common at copper-polluted stations, i.e. classified as highly tolerant species (Table 5). $\mathrm{Cu}$ : copper concentration (ppm dry weight). $\mathrm{N}$ : number of individuals $\mathrm{m}^{-2}$. The $\lg (\mathrm{Cu})$ value 2.3 corresponds to $200 \mathrm{ppm}$

lowering the diversity. One might argue that the lowered diversity was caused by some other factor, e.g. a pollutant co-occurring with copper, organic pollution, or other environmental disturbance. This explanation is less probable, since copper showed stronger correlation with lowered diversity than with lead and zinc, and the correlations between lowered diversity and lead or zinc were moderate or low (Table 1). One would not expect copper to be more closely correlated with some unknown diversity-lowering pollutant than lead and zinc are. The results thus indicate that the correlation between copper and lowered diversity is of a cause-effect type.

Factors which can be related to organic pollution and which may also affect fauna diversity are sediment organic levels, sulphide levels, and dissolved oxygen. The sorption of copper to sediments may be affected by several factors. The stations with the lowest diversity values were located in areas which receive significant amounts of copper. There, the input of copper from the pollution sources certainly overrides natural factors such as grain size, organic content, or sulphide levels in determining sediment copper concentration. Moreover, the hypothesis that sediment organic content affects net copper sorption (e.g. Jaffé \& Walters 
1977) cannot be generally accepted, as the present results from Norwegian fjord basins show (Fig. 4).

Extreme values of sediment copper (> $500 \mathrm{ppm}$ ) and sediment organic content co-occurred because the most copper-polluted stations were situated in areas also receiving organic pollution. However, a greater correlation was found between diversity and copper than between diversity and organic matter (Fig. 5 \& 6). Organic loading of a water body causes oxygen consumption to rise. If the water renewal is limited, oxygen depletion may result. Deep-water samples from fjord areas with low fauna diversity and high sediment copper showed oxygen concentrations above $4 \mathrm{mll}^{-1}$ in most cases. Measurements in the fjords spanned several years and covered different seasons. The lowest oxygen value, $2.27 \mathrm{ml} \mathrm{l}^{-1}$, was recorded close to the bottom in the innermost part of Sorfjorden (Skei 1975). Rosenberg (1980) reviewed benthic faunal reactions to oxygen deficiency in 10 fjords and estuaries in northern Europe. Number of species, abundance, biomass and species composition changed abruptly at $2 \mathrm{mg}$ $\left(=1.4 \mathrm{ml}\right.$ ) oxygen $l^{-1}$. Distribution patterns of benthic species in low-oxygen zones in the Black Sea and on the Californian coast showed a marked increase in the diversity at oxygen levels above $1.0 \mathrm{ml} \mathrm{l}^{-1}$ (Rhoads \& Morse 1971).

Sediment sulphide data were not available. The relatively high oxygen values would indicate that sediment sulphide levels were low. Nor were data on grain-size distribution available. Sediments in the fjord basins are of a fine-grain type, which does not vary much, and would not be expected to correlate closely with pollution. In conclusion, it seems improbable that there might be any pollutant, or pollutioninduced change in sediments, that has been more important than copper in causing lowered diversity.

On the basis of the existing data, a threshold value of copper concentration which may cause toxic effects cannot be fixed with certainty. It does seem, though, that concentrations elevated only 5 times above background levels in fjord sediments -20 to $30 \mathrm{mg}$ ( $\mathrm{kg}$ dry sediment $)^{-1}(=$ ppm) (Skei \& Paus 1979) - may have an effect.

The benthic fauna is exposed to metals dissolved in the sediment pore-water as well as to metals adsorbed to particles which the animals are in contact with or ingest. Data on copper concentrations in the porewater were not available for the stations included in the present study. Probably, free ionic copper in porewater is important. It can however be assumed that total sediment copper and bioavailable copper were correlated.

The high proportion of carnivorous polychaetes among the tolerant species indicates that they are less affected by high sediment copper concentrations than the deposit feeders are. One explanation for this difference is that the deposit feeders have to ingest more copper per nutritional unit than the carnivores do. However, some of the most common species at highly copper-polluted stations were deposit feeders (e.g. Chaetozone setosa). This supports the hypothesis that physiological differences in copper tolerance exist between species of the same feeding type.

Copper is the most toxic metal to marine organisms with the exception of mercury and silver (Bryan 1976). An impressive body of information exists on the biological importance of copper in the marine environment (reviewed by Lewis \& Cave 1982). With very few exceptions, all effect studies were related to water concentrations of the metal, and did not include species encountered in grab samples from Norwegian fjords. LC $_{50}$ values spanned 4 orders of magnitude for the invertebrates tested. One of the species common at highly copper-polluted stations in the Norwegian fjords, the polychaete Capitella capitata, had a $\mathrm{LC}_{50}$ value of $0.2 \mathrm{mg}^{-1}$ (Reish et al. 1976).

Pesch \& Morgan (1978) and Pesch (1979) found that the polychaete Neanthes arenaceodentata was less affected by copper when sediment was present in the exposure chamber. Sediment type also influenced the results of the bioassays. Worms in mud, a sediment with a high organic content and small grain size, were affected at a slower rate by copper than those in sand.

The observed reduction in the diversity of benthic species following dredging operations in a Swedish fjord was ascribed to the increased amount of suspended particles, although an increase in copper and other heavy metals was observed (Rosenberg 1977). Near a petroleum refinery, Oyenekan (1983) found a negative correlation between copper and number of species at 2 sites polluted with copper and hydrocarbons. Sediment copper concentrations there ranged from 150 to $800 \mathrm{ppm}$. Bryan \& Hummerstone (1971) found that the polychaete Nereis diversicolor could live in sediments containing 4000 ppm copper. Near a lead smelter, South Australia, Ward \& Young (1982) found a depauperated epibenthic seagrass fauna. The effects were correlated with the concentration of contaminant metals in the sediments $(\mathrm{Cd}, \mathrm{Cu}, \mathrm{Pb}, \mathrm{Mn}$ and $\mathrm{Zn}$ ).

Copper tailings have affected the macroinvertebrates in fresh-water environments. In Lake Superior the abundant amphipod Pontoporeia hoyi was not found in areas where sediment copper concentrations ranged from 395 to $1,310 \mathrm{ppm}$, but occurred in areas where mean levels were 14 to $298 \mathrm{ppm}$. Density of $P$. hoyi showed significant negative correlation with copper (Kraft 1979). Kraft \& Sypniewski (1981) examined benthic fauna and sediment copper in 2 areas of the Keweenaw Waterway, Lake Superior. The northem 
area, downdrift from deposits of copper tailings, had an average sediment copper content of $589 \mathrm{ppm}$. The southern area had an average sediment copper content of $33 \mathrm{ppm}$. The number of invertebrates was 4.3 times greater in the southern than in the northern area. The average number of taxa at southern stations was 20 and at northern stations 8 . The likely cause of the reduced fauna in the northern area was the high level of sediment copper. The results from Lake Superior correspond well to the results from the Norwegian fjords and indicate a similar cause-effect relation between elevated sediment copper and reduced fauna in marine and freshwater environments.

\section{LITERATURE CITED}

Bryan, G. W. (1976). Heavy metal contamination in the sea. In: Johnston, R. (ed.) Marine pollution. Acad. Press, London, p. 185-302

Bryan, G. W., Hummerstone, L. G. (1971). Adaptations of the polychaete Nereis diversicolor to estuarine sediments containing high concentrations of heavy metals. I. General observations and adaptation to copper. J. mar. biol. Ass. U.K. 51: 845-863

Fauchald, K., Jumars, P. A. (1979). The diet of worms: A study of polychaete feeding guilds. Oceanogr. mar. Biol. A. Rev. 17: $193-284$

Gray, J. S. (1979). The development of a monitoring program for Norway's coastal marine fauna. Ambio 8: 176-179

Gray, J. S., Mirza, F. B. (1979). A possible method for the detection of pollution-induced disturbance on marine benthic communities. Mar. Pollut. Bull. 10: 142-146

Gray, J. S., Pearson, T. H. (1982). Objective selection of sensitive species indicative of pollution-induced change in benthic communities. I. Comparative methodology. Mar. Ecol. Prog. Ser. 9: 111-119

Hovgaard, P. (1973). A new system of sieves for benthic samples. Sarsia 53: 15-18

Hurlbert, S. N. (1971). The non-concept of species diversity. Ecology 53: 577-586

Jackson, M. L. (1962). Soil chemical analysis. T. G. Evans, Watford

Jaffé, D., Walters, K. J. (1977). Intertidal trace metal concentrations in some sediments from the Humber estuary. Sci. Total Environ. 7: 1-15

Kraft, K. L. (1979). Pontoporeia distribution along the Keweenaw shore of Lake Superior affected by copper tailings. J. Great Lakes Res. 5: 28-35

Kraft, K. L., Sypniewski, R. H. (1981). Effect of sediment copper on the distribution of benthic macroinvertebrates in the Keweenaw Waterway. J. Great Lakes Res. 7: 258-263
Leppäkoski, E. (1975). Assessment of degree of pollution on the basis of macrozoobenthos in marine and brackishwater environments. Acta Acad. Abo. Ser. B, 35: 1-90

Lewis, A. G., Cave, W. R. (1982). The biological importance of copper in oceans and estuaries. Oceanogr. mar. Biol. A. Rev. 20: 471-695

Niemistö, L. (1974). A gravity corer for studies of soft sediments. Meerentutkimuslait. julk. 238: 33-38

Oyenekan, J. A. (1983). Production and population dynamics of Capitella capitata. Arch. Hydrobiol. 98: 115-126

Pearson, T. H., Gray, J. S., Johannessen, P. J. (1983). Objective selection of sensitive species indicative of pollutioninduced change in benthic communities. 2. Data analysis. Mar. Ecol. Prog. Ser. 12: 237-255

Pearson, T. H., Rosenberg, R. (1978). Macrobenthic succession in relation to organic enrichment and pollution of the marine environment. Oceanogr. mar. Biol. A. Rev. 16: 229-311

Pesch, C. E. (1979). Influence of three sediment types on copper toxicity to the polychaete Neanthes arenaceodentata. Mar. Biol. 52: 237-245

Pesch, C. E., Morgan, D. (1978). Influence of sediment in copper toxicity tests with the polychaete Neanthes arenaceodentata. Wat. Res. 12: 747-751

Reish, D. J., Martin, J. M., Piltz, F. M., Word, J. Q. (1976). The effect of heavy metals on laboratory populations of two polychaetes with comparisons to the water quality conditions and standards in Southern California marine waters. Wat. Res. 10: 299-302

Rhoads, C. D., Morse, J. W. (1971). Evolutionary and ecologic significance of oxygen-deficient marine basins. Lethaia 4 : $413-428$

Rosenberg, R. (1977). Effects of dredging operations on estuarine benthic macrofauna. Mar. Pollut. Bull. 8: $102-104$

Rosenberg, R. (1980). Effect of oxygen deficiency on benthic macrofauna. In: Freeland, H. J., Farmer, D. M., Levings, C. D. (ed.) Fjord oceanography. Plenum Publ. Corp., New York, p. 499-514

Rygg, B. (1984). Blotbunnfaunaundersøkelser. Et godt verktøy ved marine resipientvurderinger. Report, Norw. Inst. Water Research, Oslo

Rygg, B., Skei, J. (1984). Correlation between pollutant load and the diversity of marine soft-bottom fauna communities. In: Proceedings of the International Workshop on Biological Testing of Effluents (and Related Receiving Waters). OECD/U.S.EPA/Environ. Canada, p. 153-183. (Reprinted at Norw. Inst. Water Res., Oslo)

Skei, J. (1975). The marine chemistry of Sørfjorden, west Norway. Ph. D. thesis, Univ. of Edinburgh

Skei, J., Paus, P. E. (1979). Surface metal enrichment and partitioning of metals in a dated sediment core from a Norwegian fjord. Geochim. cosmochim. Acta 43: 239-246

Ward, T. J., Young, P. C. (1982). Effects of sediment trace metals and particle size on the community structure of epibenthic seagrass fauna near a lead smelter, South Australia. Mar. Ecol. Prog. Ser. 9: 137-146 